\title{
Anal Cancer pT4 TNM Finding v6 and v7
}

National Cancer Institute

\section{Source}

National Cancer Institute. Anal Cancer pT4 TNM Finding v6 and v7. NCI Thesaurus. Code C67542.

Anal cancer with tumor of any size that invades adjacent organ(s); e.g. vagina, urethra, bladder. Direct invasion of the rectal wall, perirectal skin, subcutaneous tissue, or the sphincter muscle(s) is not classified as T4. (from AJCC 6th and 7th Eds.) 